\title{
A fresh approach to tobacco control: raising the minimum legal age for access
}

\author{
John Oyston BMedSci MBBS
}

— Cite as: CMAJ 2017 February 27;189:E293-4. doi: 10.1503/cmaj.161489

A s evidence about the harm caused by tobacco smoking accumulated, physicians encouraged people to quit smoking. Subsequently, because governments were convinced that many cancers and other diseases were associated with smoking, and were apprised of their associated costs, public health measures (e.g., banning cigarette advertising) began to gain traction. Once the dangers of second-hand smoke were understood, smoking in public places was prohibited. Now that we know that the addictive substance nicotine is a neurotoxin that damages the developing brain, from fetal life to young adulthood, a new measure is needed to protect young people from tobacco. Increasing the minimum legal age for access to tobacco products to 21 or even 25 years would reduce smoking initiation substantially, reduce the prevalence of smoking, improve health across the lifespan, improve the outcome of many teenage pregnancies and save lives.

To maintain profits, the tobacco industry needs to replace customers lost to death or quitting. The industry targets young people as "replacement smokers" because they are more likely than adults to start smoking. Industry documents state: "If a man has never smoked by age 18 , the odds are three-to-one he never will. By age 24, the odds are twenty-to-one." $\mathrm{A} 2012$ report from the National Survey of Drug Use and Health in the United States confirmed that $88.5 \%$ of smokers start smoking before age 21 and $96.8 \%$ before age $25 .{ }^{2}$ A 2016 report from the US Surgeon General highlighted that nicotine exposure during adolescence can disrupt the development of brain regions that control attention, learning and susceptibility to addiction; furthermore, the substance may lead to mood disorders and to deficits in attention and cognition. ${ }^{3}$

Teenagers typically exhibit risk-taking behaviour because the prefrontal cortex, needed for planning and impulse control, does not fully mature until about age 25 years. ${ }^{4}$ About 87000 Canadians start smoking every year. ${ }^{5}$ In Canada, there are 201000 teenagers aged 15-19 years who smoke. ${ }^{6}$ Three-quarters of those teenagers will continue to smoke as adults. Half of those, about 75000 adults, will die prematurely of tobacco-related diseases. Early smoking initiation results in people smoking more, for longer and having greater difficulty quitting. ${ }^{2}$

The World Health Organization Framework Convention on Tobacco Control (available at www.who.int/tobacco/framework/ WHO_FCTC_english.pdf) requires participating countries to pro-

\section{KEY POINTS}

- As evidence has accumulated regarding the substantial harm caused by using tobacco, progressive public health measures have been instituted to reduce population exposure.

- The human brain continues to develop until age 25 years; exposure of the developing brain to the neurotoxic effects of nicotine increases the risk of drug-seeking behaviour and mood disorders.

- Early smoking initiation increases the amount people smoke and makes it more difficult for them to quit.

- Raising the minimum legal age for buying tobacco to at least age 21 years, as instituted in many jurisdictions, would reduce smoking initiation, reduce overall smoking prevalence, prevent diseases associated with tobacco throughout the life course and save lives.

hibit the sale of tobacco products to people under 18 years of age. Most countries have a minimum legal age of 18 or 19 years, but it can be as low as 14 (e.g., in Egypt and Malawi) or 16 (e.g., in Austria and Belgium). In Japan, the minimum legal age for purchasing tobacco is 20 years; it is 21 in Guam, Honduras, Kuwait, Samoa, Sri Lanka, Uganda and some parts of the US. In Canada, the federal minimum legal age is 18 years. However, six provinces - British Columbia, New Brunswick, Newfoundland and Labrador, Nova Scotia, Ontario and Prince Edward Island - have raised the minimum legal age to 19 years (even though the age of majority is 18 years in Ontario and Prince Edward Island). Overall smoking prevalence across those six provinces is $11.7 \%$ compared with $14.8 \%$ in the four provinces where the minimum legal age is 18 years. ${ }^{6}$

In 2015, the US Institute of Medicine published a report on the public health effects of raising the minimum legal age to 19,21 or 25 years. ${ }^{2}$ It concluded that a minimum legal age of 21 years would reduce the smoking initiation rate among 15 - to 17 -year-olds by $25 \%$, lead to 50000 fewer cases of lung cancer and prevent 223000 early deaths in the US. A reduction in smoking by teenage mothers would improve pregnancy outcomes and decrease the incidence of sudden infant death syndrome by $16 \%$. The report recognized that raising the minimum legal age to 25 years would have a greater effect but would be harder to achieve politically. ${ }^{2}$ 
In 2006, the community of Needham, Massachusetts, increased the minimum legal age for tobacco to 21 . The prevalence of smoking in its high schools declined by $47 \% .{ }^{7}$ Hawaii, California and over 200 municipalities, encompassing 62 million Americans, are now covered by "Tobacco 21" laws. Many states have similar laws in development. In the US, 75\% of adults (and 70\% of smokers) support raising the minimum legal age to 21 years, as do youth groups and many medical associations, and the New England Journal of Medicine called it "An idea whose time has come."

A recent survey in Canada found that $80 \%$ of smokers would support a law to raise the minimum legal age to 21 years. ${ }^{9}$ This idea is supported by the Ontario Tobacco Research Unit. ${ }^{10}$ An online petition to raise the minimum legal age has garnered over 13000 signatures. The Canadian Coalition for Action on Tobacco has called for a ramping up of tobacco-control efforts - to provide Canadians with "first class protection" from the tobacco industry - saying that progress has been too slow and has caused many avoidable deaths. ${ }^{11}$

The movement is gaining momentum. Recently, federal Minister of Health, Dr. Jane Philpott, announced a national forum on tobacco control, stating "The Government of Canada is continuing to explore new and better ways to address smoking ... to ensure Canada remains a leader in tobacco control." ${ }^{5}$ Both the Federal Tobacco Control Strategy and Ontario's Smoke-Free policy are overdue for renewal. In BC, the Minister of Health has asked for public input on raising the minimum legal age to 21 years.

Canada should pass federal legislation banning the supply of all tobacco and nicotine-containing products - excluding smoking cessation products - to anyone under the age of 21 . It should strictly enforce that law but not penalize people under 21 who purchase, possess or smoke tobacco, because they should not be regarded as criminals. This law should be phased in over two or three years so that people who are legal smokers are not forced to quit abruptly.

Critics point out that many people start smoking before they reach the current minimum legal age. However, young teenagers usually acquire their tobacco products through friends or siblings who are (or appear to be) of legal age. With a minimum legal age of 21 years, there would be few students in high school who would be old enough to buy tobacco products for younger students.

Some might argue that 18-year-olds are adults because they may enlist in the armed forces. However, smoking is more deadly than serving in the Canadian Armed Forces. Serving in the armed forces has benefits both to the individual and to society. Smoking benefits no one.

As physicians, we should spare no effort in preventing young people from starting to smoke. Eighteen or 19 is too young to be allowed legal access to an addictive and carcinogenic product that can never be used safely. Raising the minimum legal age for access to tobacco is a scientifically proven, legally and politically feasible, quick, cheap and effective way to deprive the tobacco industry of recruiting a new generation of young people as their customers.

\section{References}

1. Burrows DS. Estimated change in industry trend following federal excise tax increase [letter]. RJ Reynolds Records, Minnesota Litigation Documents. San Francisco (CA): UCSF Medical Center; 1982. Available: https://www.industry documentslibrary.ucsf.edu/tobacco/docs/nnnw0084 (accessed 2017 Jan. 25).

2. Bonnie RJ, Stratton K, Kwan LY, editors. Public health implications of raising the minimum age of legal access to tobacco products. Washington (DC): National Academies Press; 2015. Available: https://www.ncbi.nlm.nih.gov/books/ NBK310412/ (accessed 2017 Jan. 25).

3. E-cigarette use among youth and young adults: a report of the surgeon general. Atlanta: US Department of Health and Human Services, Centers for Disease Control and Prevention, National Center for Chronic Disease Prevention and Health Promotion, Office on Smoking and Health; 2016. Available: https://e-cigarettes. surgeongeneral.gov/documents/2016_SGR_Full_Report_non-508.pdf (accessed 2017 Jan. 25).

4. Steinberg L. A social neuroscience perspective on adolescent risk-taking. Dev Rev 2008;28:78-106.

5. Government of Canada announces next steps in tobacco control [news release]. Ottawa: Health Canada; 2016 Sept. 27. Available: http://news.gc.ca/web/article -en.do?nid=1130369 (accessed 2017 Jan. 25).

6. Canadian tobacco, alcohol and drugs survey, 2015 updated. Ottawa: Statistics Canada [The Daily]; 2016. Cat no 11-001-X. Available: http://statcan.gc.ca/daily -quotidien/161109/dq161109b-eng.pdf (accessed 2017 Feb. 7).

7. Kessel Schneider S, Buka SL, Dash K, et al. Community reductions in youth smoking after raising the minimum tobacco sales age to 21 . Tob Control 2016; 25:355-9.

8. Winickoff JP, Gottlieb M, Mello MM. Tobacco 21 - an idea whose time has come. N Engl J Med 2014;370:295-7.

9. Chung-Hall J, Craig L, Driezen P, et al. Canadian smokers' support for tobacco endgame strategies: findings from the ITC Canada Survey: a report prepared for the 2016 Canadian Tobacco Endgame Summit. ITC Project. Waterloo (ON): University of Waterloo; 2016. Available: www.itcproject.org/resources/view/2383 (accessed 2017 Jan. 25).

10. Pope M, Chaiton M, Schwartz R. Raising the minimum age for access to tobacco to 21. OTRU Update. Toronto: Ontario Tobacco Research Unit; 2015. Available: http://otru.org/wp-content/uploads/2015/08/update_august2015.pdf (accessed 2017 Jan. 25).

11. Canadian coalition for action on tobacco [press release]. Ottawa: Physicians for a Smoke-Free Canada; 2015. Available: www.smoke-free.ca/eng_home /2015/news_press_29_May_2015.htm (accessed 2017 Feb. 14).

\section{Competing interests: None declared.}

Affiliations: Scarborough Rouge Hospital, Scarborough, Ont.; Department of Anesthesia, University of Toronto; Tobacco21.ca, Toronto, Ont.

This article has been peer reviewed.

Correspondence to: John Oyston, johnpoyston@gmail.com 